Małgorzata Mikita ${ }^{1}$

\title{
UNIA BANKOWA A STABILNOŚĆ SYSTEMU FINANSOWEGO UE
}

\section{Wprowadzenie}

Unia bankowa to nowa koncepcja Unii Europejskiej w zakresie integracji rynku finansowego. Pomysł utworzenia unii bankowej zrodził się po globalnym kryzysie finansowym, który rozpoczął się w 2007 r. w Stanach Zjednoczonych, a następnie rozprzestrzenił się na inne kraje świata, w tym kraje UE. System finansowy UE okazał się być nieodporny na zagrożenia płynące z zewnątrz. Jego stabilność została zachwiana. Unia bankowa ma przeciwdziałać podobnej sytuacji w przyszłości. Priorytetem unii bankowej jest wzmocnienie systemu finansowego UE.

Celem artykułu jest analiza wpływu unii bankowej na stabilność systemu finansowego UE. Dokonując analizy, zwróciłam uwagę na trzy filary unii bankowej, tj. jednolity mechanizm nadzorczy, jednolity mechanizm restrukturyzacji i uporządkowanej likwidacji oraz jednolity system gwarantowanych depozytów.

Artykuł składa się z trzech części. W pierwszej z nich przedstawiłam system finansowy UE, zwracając uwagę na obecny poziom integracji tego systemu w ramach UE, a także trendy, jakie można było obserwować w okresie ostatnich kilkunastu lat. W drugiej części przybliżyłam istotę unii bankowej, wskazując na jej trzy podstawowe filary. Trzecia część to analiza skutków ustanowienia unii bankowej dla stabilności systemu finansowego UE.

W artykule stawiam hipotezę, iż unia bankowa to projekt, który ma szansę przyczynić się do zwiększenia stabilności systemu finansowego UE, niemniej jednak jest to projekt niewystarczająco gwarantujący tę stabilność.

\footnotetext{
1 Dr Małgorzata Mikita, Katedra Finansów i Bankowości, Wydział Ekonomii i Zarządzania, Uczelnia Łazarskiego w Warszawie.
} 


\section{System finansowy UE}

Na system finansowy UE składają się systemy finansowe poszczególnych krajów członkowskich. Mimo trwających od wielu lat prac w zakresie ujednolicenia tego systemu i wprowadzenia jednolitych zasad dla funkcjonowania instytucji finansowych i rynków finansowych na obszarze całej UE jak dotychczas nie udało się tego osiągnąć. Kraje UE pozostają nadal krajami o zróżnicowanych rozwiązaniach prawnych w zakresie systemów finansowych. Pewne zróżnicowanie obserwuje się dodatkowo w odniesieniu do rodzaju instytucji finansowych działających na poszczególnych rynkach i oferowanych przez nie produktów, jak też przyjętych rozwiązań w zakresie infrastruktury finansowej czy stopnia rozwoju poszczególnych segmentów rynku finansowego. Ponadto efektywność i stabilność działania instytucji finansowych i rynków finansowych w różnych krajach jest różna.

Silne dążenie UE do ujednolicenia zasad działania rynków finansowych obserwuje się już od 1999 r. Wtedy to UE wskazała, iż jednym z jej celów jest stworzenie rynku o swobodnym przepływie kapitałów między krajami członkowskimi i swobodzie świadczenia usług finansowych, czyli zbudowanie tzw. jednolitego rynku finansowego. Realizacja pomysłu zaczęła się od opracowania dokumentu o nazwie Financial Services Action Plan (FSAP), który pozwolił na stworzenie podstaw prawnych jednolitego rynku finansowego. Wydano wówczas wiele dokumentów (dyrektyw, rozporządzeń, rekomendacji, decyzji, komunikatów), w których określono wytyczne, na jakich ma się opierać ten rynek. Wspólne wytyczne dotyczyły zasad obrotu instrumentami finansowymi na rynku europejskim, standaryzacji informacji zawartych w prospektach emisyjnych, zasad działania funduszy inwestycyjnych na rynku UE, wymogów kapitałowych dla banków oraz firm ubezpieczeniowych, regulacji skierowanych do agencji ratingowych, wspólnych standardów w zakresie rachunkowości czy zasad dotyczących obrotu instrumentami pochodnymi. Proces wdrażania przepisów unijnych do prawodawstwa poszczególnych krajów UE trwa do chwili obecnej i jest realizowany $\mathrm{z}$ różną intensywnością $\mathrm{w}$ różnych krajach. To powoduje, że niektóre segmenty rynku finansowego są lepiej zintegrowane niż inne. Najlepiej zintegrowanymi obecnie segmentami są: międzybankowy rynek pieniężny i rynek obligacji. Segmentami o małym stopniu integracji są: rynek bankowości detalicznej oraz rynek akcji. W UE obrót obligacjami dokonywany jest głównie na wspólnej platformie obrotu zarządzanej w ramach grupy Mercado dei Titoli de Stato (MTS). W przypadku rządowych papierów wartościowych (obligacje, bony skarbowe) MTS kontroluje obrót na 13 rynkach państw członkowskich Unii - w Austrii, Belgii, Danii, Hiszpanii, Polsce, Francji, Finlandii, Grecji, Holandii, Niemczech, Irlandii, Portugalii 
i we Włoszech. Nie ma regulacji rynku akcji na szczeblu unijnym. Każdy kraj określa własne przepisy dotyczące rynku akcji, jakkolwiek przepisy te są konstruowane $\mathrm{z}$ uwzględnieniem pewnych wytycznych zawartych w dyrektywach unijnych.

Niewątpliwie elementem integrującym system finansowy w ramach UE są pewne elementy infrastruktury finansowej, takie jak międzynarodowe systemy płatności czy jednolity obszar płatności w euro.

Przykładem systemów płatności działających na obszarze UE są: TARGET $2^{2}$, Euro 1, STEP 1 czy STEP 2. Systemy te umożliwiają dokonywanie rozliczeń między podmiotami pochodzącymi z różnych krajów UE. TARGET 2 to transeuropejski zautomatyzowany błyskawiczny system rozrachunku brutto w czasie rzeczywistym. Jest jednym z największych na świecie systemów rozliczających płatności wysokokwotowe. Działa od listopada 2007 r. (zastąpił działający od 1999 r. system TARGET). System Euro 1 to wysokokwotowy system rozliczeniowy typu netto dla płatności w euro. Płatności rozliczane są bezgotówkowo w sposób ciągły. System Euro 1 działa od stycznia 1999 r. Jest systemem prywatnym. Jego twórcą jest Europejskie Stowarzyszenie Bankowe (Euro Banking Association - EBA), a operatorem - Spółka Rozliczeniowa EBA Clearing Company (EBA). System STEP 1 jest europejskim systemem transgranicznym rozliczającym płatności detaliczne w euro. Służy do rozliczania płatności klientów banków w formie uznaniowych zleceń płatniczych. Funkcjonuje od 2000 r. System STEP 2 działa jak automatyczna izba rozliczeniowa obejmująca swoim zakresem działania państwa Europejskiego Obszaru Gospodarczego (EOG) ${ }^{3}$. Został uruchomiony w $2003 \mathrm{r}$.

Jednolity obszar płatności w euro (Single Euro Payment Area - SEPA) to obszar, w którego ramach konsumenci, przedsiębiorcy i inne podmioty z krajów UE mogą dokonywać bezgotówkowych rozliczeń w walucie euro na terenie UE, zarówno transgranicznie, jak i w granicach państw członkowskich, według takich samych zasad i na takich samych warunkach. Standardami SEPA są objęte następujące instrumenty płatnicze: polecenie przelewu, polecenie zapłaty oraz karty płatnicze. Opracowano zbiór reguł wyznaczających standardy dla dwóch pierwszych rodzajów instrumentów oraz jednolite ramy prawne dla kart płatniczych ${ }^{4}$.

Globalny kryzys finansowy unaocznił, iż działania podejmowane przez UE w ramach harmonizacji systemu finansowego były niewystarczające. Okazało się, że sektor ten jest mało odporny na kryzysy finansowe, czyli stopień jego stabilności jest

2 https://www.ecb.europa.eu/paym/t²/html/index.en.html [dostęp 20.08.2016].

3 EOG powstał w 1994 r. w celu rozszerzenia przepisów Unii Europejskiej dotyczących jej rynku wewnętrznego na państwa będące członkami Europejskiego Stowarzyszenia Wolnego Handlu (EFTA). Członkami EOG są kraje UE oraz trzy kraje EFTA - Islandia, Liechtenstein i Norwegia.

4 http://www.sepapolska.pl [dostęp 2.09.2016]. 
zbyt niski, co zmobilizowało UE do podjęcia nowych działań na rzecz zwiększenia tej stabilności. Jednym z pomysłów, które zostały zrealizowane, jest powołanie unii bankowej. Główne cele nowego programu to: lepsza regulacja sektora finansowego, lepszy nadzór, wprowadzenie mechanizmów zarządzania kryzysem, zwiększenie ochrony konsumentów i inwestorów, czego efektem ma być zwiększenie stabilności systemu finansowego w UE. Zadanie wydaje się bardzo ambitne, zwłaszcza w obliczu analizy trendów, jakie od kilku lat obserwuje się na rynku europejskim.

Jednym z takich trendów jest niewątpliwie wzrost znaczenia sektora finansowego w gospodarce. W wielu krajach przekracza on swoimi rozmiarami sferę realną gospodarki. Operacje finansowe przeprowadzane na rynku finansowym są w coraz większym zakresie oderwane od procesu produkcji i świadczenia usług. Rośnie liczba fuzji i przejęć, co doprowadza do powstania instytucji o bardzo dużych rozmiarach. Instytucje te obecnie są postrzegane jako element ryzyka systemowego $z$ uwagi na to, iż upadek każdej z nich niewątpliwie zachwiałby stabilnością systemu finansowego całej UE. Do obrotu wprowadza się ogromną liczbę nowych instrumentów finansowych (czego przykładem jest dynamiczny rozwój rynku produktów strukturyzowanych czy instrumentów pochodnych). Dynamicznie rozwija się sektor finansowy nieregulowany (np. rynek funduszy hedgingowych). Możemy również mówić o dużej automizacji sektora finansowego, wynikającej z oderwania się cen aktywów finansowych od czynników fundamentalnych ${ }^{5}$. Ponadto rośnie znaczenie kapitału państwowego w aktywach sektorów bankowych krajów UE. Przyczyną takiego stanu rzeczy jest dokapitalizowywanie banków przez poszczególne państwa w okresie kryzysu. Dokapitalizowanie przyjęło postać zakupu przez państwa nowo emitowanych akcji zagrożonych banków. Przykładowo angielski RBS otrzymał 23,4 bln euro, Lloyds - 19 bln euro, niemiecki Commerzbank - 18,2 bln euro, holenderski ING i niemiecki Bayern LB - po 10 bln euro ${ }^{6}$. Zwiększanie udziału państwa w aktywach sektora bankowego zawsze rodzi obawy o kierowanie się interesami politycznym, a nie ekonomicznymi w zarządzaniu bankiem. Co więcej, istnieje ryzyko, że banki z dużym kapitałem państwowym skupią się na działaniach tylko na własnym rynku, co może znacząco wpłynąć na zmniejszenie ich międzynarodowego charakteru. Globalny kryzys finansowy upewnił banki, iż państwa trzymają się zasady „zbyt duży, aby upaść". W sytuacji poważnych problemów finansowych duże banki otrzymały pomoc państwową. Takie działania narażają świat finansów na rozwój moral hazard. Banki, mając pewność, że w sytuacjach kryzysowych mogą liczyć na pomoc państwa, chętniej angażują się w podejmowanie działań obarczonych dużym ryzykiem.

5 W. Małecki, Przemiany sektora bankowego i ich konsekwencje, „Ekonomista” 2014, nr 4, s. 468.

6 Global banking trends after the crisis, „EU Monitor 67”, Deutsche Bank Research, Germany 2009, s. 5. 
Powstaje zatem pytanie, czy uwzględniając obecny poziom integracji systemu finansowego w ramach UE, a także trendy, jakie można było obserwować w okresie ostatnich kilkunastu lat na tym rynku, unia bankowa ma szansę na zwiększenie stabilności systemu finansowego $\mathrm{UE}^{7}$ ?

\section{Unia bankowa - istota}

Idea unii bankowej zrodziła się w reakcji na globalny kryzys finansowy, jaki rozpoczął się w 2007 r. na rynku kredytów hipotecznych w USA i szybko dotknął także inne segmenty rynku finansowego oraz inne kraje, w tym unijne. Okazało się, że krajowe nadzory nad rynkami finansowymi w poszczególnych krajach są bezradne wobec problemów paneuropejskich instytucji finansowych. Zaczęto zatem pracować nad stworzeniem europejskich mechanizmów stabilizujących sektor bankowy, co ostatecznie doprowadziło do stworzenia unii bankowej.

Koncepcja unii bankowej została przedstawiona po raz pierwszy w czerwcu $2012 \mathrm{r}$. w dokumencie „W kierunku faktycznej Unii Gospodarczej i Walutowej”. Miała ona na celu zwiększenie stabilności finansowej w strefie euro i całej UE9. Ponadto podkreślano, iż istotne jest wyeliminowanie w przyszłości sytuacji, w których do ratowania upadających banków używa się pieniędzy podatnika (co było szeroko wykorzystywane do ratowania instytucji finansowych w czasie ostatniego globalnego kryzysu finansowego).

Do unii bankowej weszły wszystkie państwa strefy euro. Pozostałe kraje UE mają natomiast możliwość przyłączenia się do niej na zasadzie bliskiej współpracy (Polska nie należy obecnie do unii bankowej).

Istotę unii bankowej najlepiej oddaje określenie, iż jest to unijny system nadzoru nad bankami oraz ich restrukturyzacji i uporządkowanej likwidacji funkcjonujący na podstawie unijnych przepisów. Unia bankowa składa się z trzech elementów (nazywa się je filarami unii bankowej). Są to:

\footnotetext{
7 Stabilność systemu finansowego jest rozumiana jako stan, w którym system finansowy pełni swoje funkcje w sposób ciągły i efektywny, nawet wtedy, gdy na rynku pojawiają się nieoczekiwane zaburzenia o zabarwieniu negatywnym. Raport o stabilności systemu finansowego, NBP, Warszawa, lipiec 2013, s. 3.

8 W kierunku faktycznej unii gospodarczej i walutowej, Sprawozdanie przewodniczącego Rady Europejskiej Hermana Van Rompuya, Bruksela 2012, http://www.consilium.europa.eu/uedocs/cms_data/docs/pressdata/PL/ec/131295.pdf [dostęp 4.09.2016].

9 D. Schoenmaker, A. Siegmann, Efficiency Gains of European Banking Union, „Tinbergen Institute Discussion Paper" 2013, s. 2.
} 
- jednolity mechanizm nadzorczy (Single Supervisory Mechanizm - SSM),

- jednolity mechanizm restrukturyzacji i uporządkowanej likwidacji (Single Resolution Mechanism - SRM),

- jednolity system depozytów gwarantowanych (Single Deposit Guarantee Scheme - SDGS).

Jednolity mechanizm nadzorczy to pierwszy filar unii bankowej. W ramach tego filaru ustanowiono Europejski System Nadzoru Finansowego. W skład Europejskiego Systemu Nadzoru Finansowego wchodzą:

- Europejska Rada ds. Ryzyka Systemowego (European Systemic Risk Board - ESRB $)^{10}$, której zadaniem jest monitorowanie ryzyka systemowego ${ }^{11}$,

- cztery Europejskie Urzędy Nadzoru (European Supervisory Authorities - ESA), tj.:

- Europejski Urząd Nadzoru Bankowego (European Banking Authority - EBA) ${ }^{12}$,

- Europejski Urząd Nadzoru Ubezpieczeń i Pracowniczych Programów Emerytalnych (European Insurance and Occupational Pensions Authority - EIOPA) ${ }^{13}$,

- Europejski Urząd Nadzoru Giełd i Papierów Wartościowych (European Securities and Markets Authority - ESMA) ${ }^{14}$,

- Wspólny Komitet Europejskich Urzędów Nadzoru (Joint Committee),

- właściwe organy lub organy nadzoru państw członkowskich określone w odpowiednich aktach unijnych.

Szczególną rolę w ramach jednolitego mechanizmu nadzorczego odgrywa Europejski Bank Centralny. W Rozporządzeniu Rady UE z dnia 15 października $2013 \mathrm{r}$. w sprawie jednolitego mechanizmu nadzorczego przewidziano, że od listopada $2014 \mathrm{r}$. określone zadania związane z nadzorem ostrożnościowym nad instytucjami kredytowymi zostaną powierzone właśnie temu bankowi ${ }^{15}$. Bezpośredniemu nadzorowi EBC podlegają banki, których aktywa przekraczają $30 \mathrm{mld}$ euro lub stanowią przynajmniej 20\% PKB ich państwa. Obecnie w strefie euro jest około 120 takich banków. Ich aktywa odpowiadają $85 \%$ wszystkich aktywów bankowych strefy ${ }^{16}$.

10 http://www.esrb.europa.eu/home/html/index.en.html [dostęp 27.09.2016].

11 P. Smuga, Wpływ Europejskiej Rady Ryzyka Systemowego na stabilność finansowa UE, „Gospodarka Narodowa" marzec 2013.

12 http://www.eba.europa.eu/languages/home_pl [dostęp 17.08.2016].

13 https://eiopa.europa.eu/ [dostep 23.08.2016].

14 https://www.esma.europa.eu/ [dostęp 18.08.2016].

15 Rozporządzenie Rady (UE) nr 1024/2013 z dnia 15 października 2013 r. powierzające Europejskiemu Bankowi Centralnemu szczególne zadania w odniesieniu do polityki związanej z nadzorem ostrożnościowym nad instytucjami kredytowymi, http://eur-lex.europa.eu/legal-content/pl/TXT/PDF/?uri=CELEX:32013R1024\&from=EN [3.09.2016].

16 Pod poniższym adresem znajduje się lista banków nadzorowanych przez EBC: http://www.ecb.europa. eu/pub/pdf/other/ssm-listofsupervisedentities1409en.pdf?7f491a3d1ffd265b97f0ed2d9a7d939e [dostęp 8.08.2016]. 
Celem jednolitego mechanizmu restrukturyzacji i uporządkowanej likwidacji jest zapewnienie skutecznej restrukturyzacji oraz likwidacji niewypłacalnych instytucji finansowych ${ }^{17}$. W ramach jednolitego mechanizmu restrukturyzacji i uporządkowanej likwidacji powołano Jednolitą Radę ds. Restrukturyzacji i Uporządkowanej Likwidacji (Single Resolution Board - SRD), która pełni rolę organu decyzyjnego, oraz Jednolity Fundusz Restrukturyzacji i Uporządkowanej Likwidacji (Single Resolution Fund - SRF), który pełni funkcję zabezpieczenia finansowego ${ }^{18}$. W ramach procesu restrukturyzacji i uporządkowanej likwidacji mogą być wykorzystane różne instrumenty, np. instrument zbycia wyodrębnionej części instytucji finansowej, instrument instytucji pomostowej, instrument wydzielenia aktywów, instrument umorzenia lub konwersji długu ${ }^{19}$. SRD monitoruje wykonanie programu restrukturyzacji i uporządkowanej likwidacji poprzez krajowe organy ds. restrukturyzacji i uporządkowanej likwidacji.

W ramach jednolitego systemu gwarantowania depozytów planuje się ujednolicenie reguł prawnych ochrony depozytów do wysokości 100 tys. euro, m.in. planuje się wprowadzenie zasady, iż systemy gwarancyjne w poszczególnych krajach będą finansowane ze składek banków. Minimalny poziom funduszy w poszczególnych krajach ma odpowiadać $0,8 \%$ depozytów gwarantowanych ${ }^{20}$. Dodatkowo planuje się ujednolicenie terminu wypłaty gwarantowanych depozytów do 7 dni. Należy jednak podkreślić, że do chwili obecnej (wrzesień 2016r.) nie osiągnięto porozumienia w sprawie realizacji tego filaru. Oznacza to, że system gwarancyjny ma charakter systemów lokalnych, czyli ustalanych i monitorowanych przez poszczególne kraje.

Patrząc z perspektywy wdrożenia tych filarów w życie, można stwierdzić, że dwa pierwsze, czyli jednolity mechanizm nadzorczy oraz jednolity mechanizm restrukturyzacji i uporządkowanej likwidacji, odznaczają się dużo większym stopniem zaawansowania w porównaniu z filarem trzecim, czyli jednolitym systemem gwarantowania depozytów, który nie został jeszcze wdrożony.

$17 \mathrm{http} / / /$ www.consilium.europa.eu/pl/policies/banking-union/single-resolution-mechanism/ [dostęp 28.08.2016].

18 PWC, EU Bank Recovery and Resolution Directive „Triumph or tragedy”?, https://www.pwc.com/im/ en/publications/assets/pwc_eu_bank_recovery_and_resolution_directive_triumph_or_tragedy.pdf [dostęp 6.09.2016]

19 P. Sitek, Zintegrowany sektor bankowy Unii Europejskiej. Studium finansowo-prawne, Vizja, Warszawa 2015, s. 168 .

20 Dyrektywa Parlamentu Europejskiego i Rady 2009/14/WE z dnia 11 marca 2009 r. zmieniająca dyrektywę 94/19/WE w sprawie systemów gwarancji depozytów w odniesieniu do poziomu gwarancji oraz terminu wypłaty, http://eur-lex.europa.eu/legal-content/PL/TXT/PDF/?uri=CELEX:32009L0014\&rid=1 [dostęp 6.09.2016]. 


\section{Skutki ustanowienia unii bankowej dla stabilności systemu finansowego UE}

Od momentu powołania unii bankowej minęło niewiele $\mathrm{czasu}^{21}$. Pełna analiza skutków jej ustanowienia w oparciu o dane statystyczne nie jest zatem możliwa. Można jednak dokonać analizy potencjalnych skutków powołania unii bankowej dla stabilności systemu finansowego UE.

Jednolity mechanizm nadzorczy to niezwykle istotny element zwiększający stabilność działania systemu finansowego UE. Do momentu powołania unii bankowej nadzór nad rynkiem finansowym w poszczególnych krajach sprawowały wyłącznie krajowe organy nadzorcze. Taki model był niewątpliwie skuteczny w okresie, kiedy proces globalizacji finansowej nie był tak powszechny. Obecnie wiele instytucji finansowych, w tym banków, działa jednocześnie na wielu rynkach, co sprawia, że nadzór krajowy przestał być nadzorem skutecznym ${ }^{22}$. Pierwszy filar unii bankowej to niewątpliwie pierwszy krok do zmiany tej sytuacji. Istotną rolę w ramach jednolitego mechanizmu nadzorczego powierzono Europejskiemu Bankowi Centralnemu (EBC). Bank ten ma prawo sprawdzać, czy banki, które bezpośrednio podlegają jego kontroli, przestrzegają wymogów adekwatności kapitałowej, płynności i dźwigni finansowej. Ma możliwość żądania dostępu do informacji i przeprowadzania strestestów. Ponadto EBC może realizować programy naprawcze w bankach, ma prawo do nakładania sankcji finansowych oraz do udzielania zezwoleń instytucjom kredytowym i ich odbierania. Dotyczy to wszystkich instytucji, nie tylko tych uznanych za ważne systemowo. Obok licencji wydaje również zezwolenia na tworzenie oddziałów i podejmowanie działalności transgranicznej w krajach, które nie należą do unii bankowej $^{23}$. W strukturach EBC wyodrębniono Radę Nadzoru (Supervisory Board), która zajmuje się sprawami nadzoru. Rada przygotowuje projekty, które następnie są przedkładane do decyzji Radzie Prezesów EBC. Rada Nadzoru spotyka się dwa razy w miesiącu. W jej skład wchodzą: przewodniczący (mianowany na nieodnawialną pięcioletnią kadencję), wiceprzewodniczący (jeden z członków Zarządu EBC), czterech przedstawicieli EBC oraz przedstawiciele krajowych organów nadzoru. Jednym $\mathrm{z}$ istotnych plusów powierzenia kompetencji nadzorczych EBC jest wyeliminowanie

21 Single Supervisory Mechanism (SSM) został wprowadzony w listopadzie 2014 r., Single Resolution Board (SRM) wprowadzono w styczniu 2015 r., natomiast swoją pełną działalność rozpoczął od stycznia 2016 r. M. Hafa, European Banking Union, Three Years On, „CIGI Papers” June 2015, No. 73, s. 1.

22 J. Colliard, Optimal supervisory architecture and financial integration in a banking union, „ECB Working Paper Series" April 2015, s. 4.

23 J. Żabińska, Unia bankowa, w: Zarzadzanie gospodarcze w strefie euro, red. J. Pietrucha, J. Żabińska, Difin, Warszawa 2014, s. 86. 
sytuacji, w których władze nadzorcze poszczególnych krajów pobłażliwie podchodziły do działań największych banków, niedostatecznie wykonywały swoje zadania nadzorcze wobec nich, a czasami były wręcz podporządkowane ich interesom. Takie działanie zwiększało niebezpieczeństwo pojawienia się problemów w ramach poszczególnych instytucji, co z kolei zagrażało utracie stabilności całego systemu finansowego UE. Jednym $z$ minusów obecnych rozwiązań jest jednak obawa, iż EBC nie zdoła skutecznie realizować jednocześnie polityki pieniężnej w strefie euro, za którą jest odpowiedzialny, jak też polityki nadzorczej wobec największych banków. Wydaje się, że powołanie oddzielnego organu byłoby skuteczniejszym rozwiązaniem (ulokowanie nadzoru w EBC było spowodowane względami prawnymi, a nie ekonomicznymi - traktat z Maastricht nie pozwalał bowiem na powołanie samodzielnej instytucji).

Wprowadzone zasady w zakresie restrukturyzacji i uporządkowanej likwidacji banków niewątpliwie zwiększają stabilność systemu finansowego UE. Znoszą bowiem wyłączną odpowiedzialność rządów poszczególnych krajów UE za bezpieczeństwo ich sektora bankowego, jak również rodzą nadzieję, że banki będą w mniejszy stopniu niż dotychczas akceptować w swym działaniu ogromne ryzyko finansowe. Przed ustanowieniem unii bankowej konsekwencje upadłości banków dotykały w pierwszej kolejności rynek krajowy. Rządy poszczególnych krajów w obawie przed destabilizacją tego rynku spowodowaną upadkiem dużej instytucji finansowej były gotowe na wspieranie jej działania, co z jednej strony obciążało ich budżet (gdyż wsparcie przybierało najczęściej charakter pomocy finansowej realizowanej przy wykorzystaniu środków budżetowych, czyli pieniędzy podatników), a z drugiej było wyraźnym sygnałem dla instytucji finansowych, iż mogą narażać się na duże ryzyko (w celu osiągnięcia wysokich zysków), gdyż ich działanie nie jest zagrożone upadłością (zawsze otrzymają pomoc państwa). Drugi filar unii bankowej zmienia ten stan rzeczy. Do pokrywania strat banków są zobowiązani w pierwszej kolejności akcjonariusze, posiadacze obligacji emitowanych przez dany bank, a następnie - posiadacze depozytów o wartości powyżej 100 tys. euro. Jeżeli straty banków przekroczą $8 \%$ ich aktywów, to angażowane będą środki przewidziane w ramach drugiego filaru unii bankowej. Banki będą mogły skorzystać ze środków jednolitego funduszu naprawczego (Single Resolution Fund - SFR), który będzie dysponować środkami pochodzącymi ze składek wnoszonych przez banki. SFR jest tworzony od początku 2016r. Przewiduje się, że do końca 2024 r. (czyli do czasu zakończenia jego tworzenia) będzie dysponował funduszami o wartości $55 \mathrm{mld} \mathrm{euro}{ }^{24}$. Środki funduszu są dzielone na dwie części. Z pierwszej części, zwanej wspólną, będą mogły korzystać wszystkie kraje,

24 N. Moloney, European Banking Union: assessing its risks and resiliance, „Common Market Law Review” 2014, No. 51, s. 22. 
niezależnie od wnoszonych przez nie składek. Wysokość tej części to obecnie 40\% całości, niemniej jednak przewiduje się, że część ta będzie zwiększana w kolejnych latach ${ }^{25}$. Z drugiej części środków SFR poszczególne kraje UE będą mogły korzystać w różnej wysokości, w zależności od wielkości wnoszonych przez nie składek. Po zakończeniu tworzenia funduszu nie będzie możliwe wspieranie banków ze środków krajowych ani z mechanizmu wsparcia kapitałowego ESM, a jedynie z funduszu SFR. Jeżeli w przyszłości okazałoby się, że środki, którymi dysponuje SFR, są niewystarczające, aby skutecznie restrukturyzować banki, to fundusz będzie miał możliwość pozyskiwania dodatkowych kapitałów na rynku.

Jednolity system gwarantowania depozytów to filar, który nie został jeszcze wdrożony w życie, co więcej, jego zasady nie zostały jeszcze precyzyjnie określone. Niewątpliwe system taki zaowocowałby wzrostem zaufania deponentów do systemu bankowego, eliminowałby zjawisko tzw. runu na banki, które obserwowane było w przeszłości w czasie wielu kryzysów bankowych, jak też zmobilizowałby poszczególne kraje do większej dbałości o bezpieczeństwo depozytariuszy.

\section{Podsumowanie}

Unia bankowa to niewątpliwie projekt, który ma szansę przyczynić się do zwiększenia stabilności systemu finansowego UE, niemniej jednak nie jest to projekt doskonały w tym względzie.

Zaletą projektu jest zarysowanie nowego podejścia do banków ważnych systemowo, tj. instytucji, które w okresie ostatnich kilkunastu lat stały się generatorami podwyższonego ryzyka systemowego. Zwiększenie kontroli nad tą grupą uczestników rynku, poprzez stałe monitorowanie ich działalności oraz określenie konkretnych warunków, które muszą spełniać, zwiększa stabilność ich działania, co bezpośrednio przekłada się na stabilność całego systemu finansowego.

Ponadto unia bankowa umożliwia wcześniejszą identyfikację problemów, które mogą pojawić się na rynku finansowym, i uruchomienie mechanizmów ochronnych. Ponadto pozwala na eliminację czynników politycznych, które mają wpływ na krajowe systemy nadzorcze.

25 Directive 2014/59/EU of the European Parliament and of the Council of 15 May 2014 establishing a framework for the recovery and resolution of credit institutions and investment firms, OJ L 173, 12 June 2014. 
Nowe rozwiązania ograniczają społeczne koszty kryzysów bankowych poprzez ochronę deponentów i podatników przed skutkami tych kryzysów. Deponenci nie muszą się obawiać, że w przypadku upadku banku stracą powierzone mu pieniądze, podatnicy nie będą ponosić kosztów ratowania upadających banków.

Z punktu widzenia banków unia bankowa generuje niewątpliwie dodatkowe koszty, niemniej jednak należy podkreślić, że zmusza banki do prowadzenia działalności w sposób bezpieczniejszy, bez narażania się na zbyt duże ryzyko, co zwiększa ich stabilność i w ten sposób ogranicza potencjalne koszty związane z ich ratowaniem.

Istotnym minusem unii bankowej w aspekcie stabilności systemu finansowego jest fakt, iż unia bankowa obejmuje tylko banki. Należy zauważyć, że w ramach systemu finansowego funkcjonują również inne instytucje finansowe, np. firmy ubezpieczeniowe czy fundusze inwestycyjne, które także mogą być źródłem utraty stabilności przez system finansowy. Co więcej, w ramach systemu finansowego należałoby też spojrzeć na infrastrukturę finansową i rynki finansowe UE i opracować kompleksowy program dla całego systemu finansowego. Banki to niewątpliwe dominujący uczestnik systemu finansowego UE, lecz nie jedyny.

Kolejną słabością tego projektu jest jego zasięg. Duża część systemu finansowego UE znajduje się poza tym projektem, ponieważ przystąpienie do unii bankowej nie jest obligatoryjne dla krajów znajdujących się poza strefą euro ${ }^{26}$. Kraje te mogą przystąpić na zasadzie bliskiej współpracy, lecz nie muszą, co jest istotnym minusem w aspekcie stabilności systemu finansowego całej UE. Może się bowiem okazać, że czynnikiem wywołującym kryzys są kłopoty banków w krajach leżących poza strefą euro.

Rozpatrując projekt unii bankowej z punktu widzenia stabilności systemu finansowego, należy stwierdzić, że jest to projekt niezbędny, jakkolwiek niekompletny. Jego niezbędność wynika z konieczności zwiększenia nadzoru nad instytucjami o znaczeniu systemowym dla gospodarki. Należy zwiększyć stabilność ich działania poprzez zwiększony nadzór oraz eliminację działań o dużym ryzyku finansowym. Stabilność największych banków to jeden z podstawowych warunków stabilności całego systemu finansowego. Nie jest to jednak warunek jedyny. Niezbędne jest także zapewnienie stabilności działania innym instytucjom z sektora finansowego, budowa odpowiedniej infrastruktury finansowej, skuteczne regulacje poszczególnych segmentów rynku finansowego. Projekt unii bankowej nie obejmuje tych kwestii, co czyni go projektem niewystarczającym jeśli idzie o zapewnienie stabilności systemu finansowego UE.

\footnotetext{
26 Konsekwencje przystapienia Polski do Unii Bankowej, IBNGR, Konrad Adenauer Stiftung, Gdańsk 2014, s. 22.
} 


\section{Bibliografia}

Colliard J., Optimal supervisory architecture and financial integration in a banking union, „ECB Working Paper Series” April 2015.

Directive 2014/59/EU of the European Parliament and of the Council of 15 May 2014 establishing a framework for the recovery and resolution of credit institutions and investment firms, OJ L 173, 12 June 2014.

Dyrektywa Parlamentu Europejskiego i Rady 2009/14/WE z dnia 11 marca 2009 r. zmieniająca dyrektywę 94/19/WE w sprawie systemów gwarancji depozytów w odniesieniu do poziomu gwarancji oraz terminu wypłaty, http://eur-lex.europa.eu/legal-content/ PL/TXT/PDF/?uri=CELEX:32009L0014\&rid=1

Global banking trends after the crisis, „EU Monitor 67”, Deutsche Bank Research, Germany 2009.

Hafa M., European Banking Union, Three Years On, „CIGI Papers” June 2015, No. 73.

Konsekwencje przystapienia Polski do Unii Bankowej, IBNGR, Konrad Adenauer Stiftung, Gdańsk 2014.

Małecki W., Przemiany sektora bankowego i ich konsekwencje, „Ekonomista” 2014, nr 4, s. 468.

Moloney N., European Banking Union: assessing its risks and resiliance, „Common Market Law Review” 2014, No. 51.

PWC, EU Bank Recovery and Resolution Directive „Triumph or tragedy”?, https://www. pwc.com/im/en/publications/assets/pwc_eu_bank_recovery_and_resolution_directive_triumph_or_tragedy.pdf

Raport o stabilności systemu finansowego, NBP, Warszawa, lipiec 2013.

Rozporządzenie Rady (UE) nr 1024/2013 z dnia 15 października 2013 r. powierzające Europejskiemu Bankowi Centralnemu szczególne zadania w odniesieniu do polityki związanej z nadzorem ostrożnościowym nad instytucjami kredytowymi, http:// eur-lex.europa.eu/legal-content/pl/TXT/PDF/?uri=CELEX:32013R1024\&from=EN

Schoenmaker D., Siegmann A., Efficiency Gains of European Banking Union, „Tinbergen Institute Discussion Paper” 2013.

Sitek P., Zintegrowany sektor bankowy Unii Europejskiej. Studium finansowo-prawne, Vizja, Warszawa 2015.

Smuga P., Wpływ Europejskiej Rady Ryzyka Systemowego na stabilność finansowa UE, „Gospodarka Narodowa” marzec 2013.

W kierunku faktycznej unii gospodarczej $i$ walutowej, Sprawozdanie przewodniczącego Rady Europejskiej Hermana Van Rompuya, Bruksela 2012, http://www.consilium. europa.eu/uedocs/cms_data/docs/pressdata/PL/ec/131295.pdf

Żabińska J., Unia bankowa, w: Zarządzanie gospodarcze $w$ strefie euro, red. J. Pietrucha, J. Żabińska, Difin, Warszawa 2014. 
https://eiopa.europa.eu/

http://www.consilium.europa.eu/pl/policies/banking-union/single-resolution-mechanism/ http://www.eba.europa.eu/languages/home_pl

https://www.ecb.europa.eu/paym/t2/html/index.en.html

http://www.ecb.europa.eu/pub/pdf/other/ssm-listofsupervisedentities1409en.pdf?7f491a 3d1ffd265b97f0ed2d9a7d939e

https://www.esma.europa.eu/

http://www.esrb.europa.eu/home/html/index.en.html

http://www.sepapolska.pl

\section{Banking union and stability of financial system in EU}

Banking union is a new concept of the European Union in the field of financial market. The project aim is to strengthen the financial system and increase its resistance to crises that may arise in the future. This article aims to analyse the impact of the banking union on the stability of the financial system in the EU. Three pillars of the banking union are taken into account: single supervisory mechanism, single resolution mechanism and single deposit guarantee scheme. The author argues that the banking union can contribute to the stability of the financial system in the EU, but it cannot guarantee it.

Keywords: banking union, financial stability, bank supervision, financial system in UE

\section{Union bancaire et la stabilité du système financier de l'UE}

L'union bancaire est une nouvelle conception de l'Union Européenne (UE) concernant l'intégration du marché financier. L'union bancaire a pour priorité le renforcement du système financier en le rendant en même temps résistant aux crises qui pourraient le menacer dans l'avenir. L'objectif de l'article est d'analyser l'influence de l'union bancaire sur la stabilité du système financier de l'UE. Trois piliers de l'union bancaire ont été pris en considération, notamment le méchanisme uniforme de surveillance, méchanisme uniforme de restructuration et de résolution et le système uniforme de garantie des dépôts. L’auteure de l'article 
argue que l'union bancaire peut contribuer à la stabilité du système financier de l'UE sans pourtant pouvoir la garantir.

Mots-clés: union bancaire, stabilité financière, surveillance bancaire, système financier dans l'UE

\section{Банковский союз и стабильность финансовой системы ЕС}

Банковский союз - это новая концепция Европейского Союза (ЕС) в области финансового рынка. Приоритетом проекта является укрепление финансовой системы и увеличение ее устойчивости к кризисам, которые могут возникнуть в будущем. Цель статьи состоит в анализе влияния банковского союза на стабильность финансовой системы ЕС. Рассматриваются три столпа банковского союза: единый надзорный механизм, единый механизм санации банков и единая схема гарантирования вкладов. Автор утверждает, что банковский союз может способствовать увеличению стабильности финансовой системы ЕС, но не может ее обеспечить.

Ключевые слова: банковский союз, финансовая стабильность, банковский надзор, финансовая система ЕС 